\title{
O DOSADI: NACRT ZA MOGUĆU KRITIKU
}

\section{ERIC UŠIĆ}

Rijeka

\begin{abstract}
Članak je podijeljen na dvije cjeline: prva će se dotaknuti kontekstualnih i konceptualnih okvira te psihološko-iskustvene domene dosade; druga će se dotaknuti pitanja suvremenih potrošačkih praksi koje se sagledavaju kao prakse koje nude moguće "rješenje" protiv dosade. Prvi korak bit će skiciranje konteksta unutar kojega dosada, kao koncept i specifično stanje čovjeka, postaje društveno relevantan fenomen. Drugi korak je postavljanje konceptualnih i teorijskih okvira, gdje se daje pregled nekolicine različitih pristupa dosadi. Pomnije će se ispitati dva tipa dosade - situacijska i egzistencijalna dosada. Potom slijedi dio teksta koji se bavi pitanjem postoje li prakse koje nastoje ponuditi svojevrstan "lijek" protiv dosade. U tom će segmentu biti govora o konzumerizmu te kulturnoj i zabavnoj industriji, pri čemu će se pozornost obratiti na odnos svakodnevice, dosade i praksi "anti-dosade". Umjesto zaključka, otvorit će se pitanje može li dosada poprimiti oblik društvene kritike.
\end{abstract}

Ključne riječi: dosada, egzistencijalna dosada, situacijska dosada, konzumerizam, svakodnevica

\section{UVOD}

Tekst ${ }^{1}$ koji slijedi nastoji sagledati dosadu iz više različitih perspektiva. Odabir takvog pristupa baziran je na statusu koji dosada ima u humanistici i društvenim znanostima: dosada je relativno neistražena tema, ne postoje adekvatni i zadovoljavajući modeli proučavanja i definiranja dosade, dok je sam pojam dosade "opterećen" i prožet heterogenošću značenja i načina korištenja u svakodnevici. ${ }^{2}$ Stoga, kombinacija različitih pristupa, poput filozofske, sociološke, historijske i antropološke perspektive, može rezultirati produktivnijom analizom koja, kao što je slučaj u ovom radu, cilja na širi teorijski zahvat i širi pregled fenomena

${ }^{1}$ Tekst je izmijenjena i prilagođena verzija seminarskog rada koji je napisan pod mentorstvom prof. Hajrudina Hromadžića u sklopu kolegija Teorije svakodnevice, na Odsjeku za kulturalne studije pri Filozofskom fakultetu u Rijeci (akademska godina 2015./2016.).

${ }^{2} \mathrm{Na}$ slične je polazišne probleme u svom radu o dosadi naišao i lgor Bezinović (vidi Bezinović 2007). 
dosade. Prateći početnu postavku i oslanjajući se na relevantnu literaturu, dosadu će se analizirati kao pojmovnu i konceptualnu kategoriju, te kao emotivno iskustvo i specifično stanje čovjeka. Nakon skiciranja sociokulturnog konteksta u čijim okvirima dosada postaje društveno relevantan fenomen, pregledom teza pojedinih autora pokušat će se postaviti konceptualni okviri koji nude moguća polazišta za širi analitički pristup dosadi. $\mathrm{Na}$ tom se tragu izdvajaju situacijska i egzistencijalna dosada, dva tipa dosade koji se najčešće pojavljuju u dostupnoj literaturi. Potom, dosadu se dovodi u odnos sa suvremenim kontekstom: sagledava je se u kontekstu potrošačkih praksi te kulturne i zabavne industrije, ovdje shvaćene kao prakse i načini produkcije koji nastoje ponuditi svojevrsno "rješenje" protiv dosade. Umjesto zaključka, otvara se pitanje može li se o dosadi govoriti i u afirmativnom tonu, odnosno može li dosada poprimiti specifičan oblik društvene kritike.

\section{KRATKI POVIJESNI PREGLED I KONTEKSTUALIZACIJA}

Mnogi autori (Svendsen 2005; Toohey 2011; Conrad 1997; Musharbash 2007; Highmore 2002; Dalle Pezze i Salzani 2009) dijele slično viđenje povijesti dosade. Povijesni period u kojem uočavaju manifestaciju i "prve" pokušaje artikulacije dosade jest period moderne. U 18. stoljeću dolazi do značajnih promjena u društvenoj, ekonomskoj i političkoj sferi koje utječu na dosadu u konceptualnom i empirijskom smislu. Ključna je promjena u reorganizaciji vremena i prostora pod utjecajem razvoja procesa industrijalizacije, urbanizacije, sekularizacije i razvoja kapitalizma. Mnogi se od navedenih autora slažu kako se svojevrsnu preteču modernog oblika dosade može vočiti u religijskom i teološkom diskursu: dosadu se povezuje s latinskim pojmom acedia (Svendsen 2005; Musharbash 2007). Acedia je u ranosrednjovjekovnoj teologiji bila shvaćena kao grijeh koji proizvodi druge grijehe. Ukoliko bi redovnici i klerici "upali" u stanje acedie, dovela bi se u pitanje njihova veza s Bogom. Acedia, ili "podnevni demon", podrazumijevala je stanje apatije i duhovnog ništavila koje ugrožava ushićenost i ispunjenost Bogom, što je ujedno onemogućavalo osobu da živi religijskim i isposničkim životom. Bog je bio shvaćen kao izvor smisla; acedia se izjednačavala sa stanjem besmisla i ništavila. Ona je, dakle, bila "uvreda" prema Bogu, jer vjernik nije mogao pronaći smisao u njemu (Svendsen 2005: 22). Nakon acedie, fokus literature usmjerava se prema renesansi, gdje se melankolija ${ }^{3}$ shvaća kao najsličniji izraz i stanje koje se povezuje s dosadom. Dok se acedia veže uz sferu moralnoga, melankolija nalazi svoje uporište u psihološkoj i tjelesnoj domeni. Acedia se povezuje s dušom i klerom, melankolija s tijelom i aristokracijom (Musharbash 2007: 308). No, kada se pojavljuje dosada?

\footnotetext{
${ }^{3}$ Dalle Pezze i Salzani (2009: 9) pišu kako dosada, za razliku od melankolije, predstavlja trivijalnu emociju koja trivijalizira svijet. Naime, melankolija se povezivala sa slikom intelektualca, kralja, filozofa i umjetnika, predstavljajući psihofizičko stanje u kojem dolazi do kombinacije "bolesti i mudrosti, pasivnosti i kreativnosti”.
} 
Ovdje bi se nakratko valjalo vratiti korak unatrag i konzultirati rad Petera Tooheyja (2011) koji je posvećen historijskoj analizi dosade. Naime, može li se, i u kojem smislu, govoriti o "povijesti" dosade i o "pojavljivanju” dosade u nekom povijesnom trenutku, odnosno podrazumijeva li pojavljivanje dosade u 18. stoljeću nepostojanje dosade prije tog perioda? Odgovor bi, u ovom slučaju, bio dvostran. Prvo, dosada je, kao emotivno stanje, u različitim varijacijama nesumnjivo postojala i u društvenim formacijama prije 18. stoljeća; drugo, dosada kao široko rasprostranjen pojam, prema svim autorima čije sam radove konzultirao tijekom pisanja teksta, nije postojala prije 18. stoljeća, kada je se prvi put uvodi u, primjerice, rječnike engleskog i njemačkog jezika. Te bi dvije razine trebalo ukratko razjasniti uz pomoć Tooheyjeve analize. Toohey uočava postojanje dosade i u antici; specifičnije, npr. u rimskoj kulturi, osim uočavanja nekolicine različitih latinskih pojmova čija su značenja slična značenjima modernog pojma dosade, Toohey uočava i prakse i događaje koji se nude kao svojevrsno "rješenje" protiv dosade, poput raznih igara u rimskim amfiteatrima. S druge strane, još ranije u povijesti, u kontekstu lovačko-sakupljačkih društava Toohey uočava nedostatak "vremenske margine" koja omogućava manifestaciju dosade, s obzirom na to da su lovci-sakupljači zaokupljeni aktivnostima kojima osiguravaju temeljne uvjete života ili su, bolje rečeno, fokusirani na preživljavanje. Upravo širenje spomenute "vremenske margine", koja je uvjetovana materijalnim uvjetima života a koja se razlikuje u pojedinim društvenim formacijama kroz povijest, omogućava praćenje "povijesti" dosade. Razvoj materijalnih uvjeta života određene društvene formacije utječe i na status koji dosada ima u širem društvenom kontekstu. Drugim riječima, dosada u pojedinim društvenim formacijama poprima različita značenja, dok njena uloga u životima pojedinaca može varirati kroz različite epohe i organizacije društva. Prateći Tooheyja (2011: 156), dok je način života lovačko-sakupljačkih društava ostavljao "manje vremena" za dosadu, u rimskom se društvu ona u različitim oblicima manifestirala iako nije imala relevantan i značajan status za društvo u cjelini. Na sličan je način moguće govoriti i o acediji, odnosno melankoliji, koje predstavljaju specifična stanja i pojmove koji su bili "rezervirani" za određene socijalne grupe. Dosada je, dakle, "postojala" prije 18. stoljeća, ali se od modernog oblika razlikuje kako terminološki - u pojedinim se kulturama i društvima izražavala kroz različite pojmove - tako i društveno - u pojedinim se epohama dosada vezivala uz određene društvene položaje. $U$ tom smislu, trebalo bi preformulirati pitanje; umjesto kada se dosada "pojavljuje" ili kada dosada "nastaje", ispravnije bi bilo pitati kada dosada postaje društveno relevantan fenomen.

Dva su povijesna trenutka pritom ključna: romantizam i razvoj kapitalizma. Filozof Lars Svendsen (2005: 28) ističe da romantizam predstavlja polazišni historijski kontekst i točku razumijevanja modernog oblika dosade. U tom historijskom kontekstu i kulturno-umjetničkom pokretu koji se unutar njegovih okvira razvijao, dolazi do isticanja individualizma. U romantizmu je fokus usmjeren prema čovjeku, kao individualnom biću, prema njegovom subjektivnom stanju, iskustvu te posebice prema emocijama. Pretpostavlja se kako čovjek mora ostvariti sebe; njegov život mora biti zanimljiv, što podrazumijeva kako se u pothvatu samo-realizacije život treba "obraniti" od upadanja u stanje dosade (isto). Romantizam 
je, prema Svendsenu, definirao jasnu distinkciju između onoga što je zanimljivo i onoga što je dosadno. ${ }^{4}$ Moglo bi se reći da se pod zanimljivim podrazumijevaju ona iskustva i situacije koji pridonose razvoju i "oplemenjivanju" duha. Naglasak je na potrazi za novim iskustvima. Kategorija dosadnoga uključivala bi, stoga, iskustva i situacije koji ne doprinose intelektualnom, emotivnom i duhovnom uzdizanju, već čine upravo suprotno: ne nude nikakve mogućnosti razvoja, napredak zamjenjuju statičnošću.

U romantizmu, prema Svendsenu (isto: 21), dolazi do "demokratizacije dosade". Naime, Svendsen piše kako je u periodima koji prethode romantizmu dosada bila "rezervirana" za plemstvo. Elitni sloj društva posjedovao je ono što nižepozicionirane grupe nisu - dokolicu. Međutim, krajem 18. i tijekom 19. stoljeća društvena se paradigma mijenja pod naletom ideja prosvjetiteljstva, utjecajem Francuske revolucije, prve faze industrijalizacije, razvoja kapitalizma i romantizma. Pod utjecajem tih procesa i transformacijom društvene strukture, dosada se "slijeva" odozgo i širi se na sve razine društva. Toohey (2011: 148-149) primjećuje da teze mnogih autora izgrađene na konstruktivističkom pristupu naglašavaju upravo to razdoblje kao ono u kojem je specifična društvena, ekonomska i tehnološka konfiguracija "proizvela" dosadu. Slične stavove dijeli i sociolog Peter Conrad (1997: 466), koji ističe da je dosada koncept kasnog 18. stoljeća, u periodu sve jačeg naglaska na čovjeka kao individuu, na njegov osobni razvoj. $U$ iskustvenom smislu, za Conrada je dosada povezana s povećanjem dokolice, što se poklapa sa Svendsenovom tezom. Antropologinja Yasmine Musharbash (2007: 308) dodatno produbljuje navedeno: izdvaja i procese sekularizacije, masovne proizvodnje robe, širenje masovnih medija, vjerovanje u "pravo na sreću" svakoga pojedinca te proces birokratizacije društva ${ }^{5}$ koji proizvodi organizirano uređenje vremena i prostora. Sažimajući teze spomenutih autora, moglo bi se reći kako je proces modernizacije onaj koji je formirao historijski kontekst u kojem je dosada stekla društveno relevantan status. Prateći Svendsena (2005: 21), dosada je privilegija modernoga čovjeka.

\section{DOSADA - KONCEPTUALNI OKVIRI}

Kao što je navedeno u uvodu, dosada je u humanistici i društvenim znanostima poprilično neistražena. Stoga je teško i problematično s preciznošću definirati i zahvatiti konceptualnu širinu pojma na teorijskoj razini, ili pak sagledati dosadu iz jednog kuta, koristeći pritom

\footnotetext{
${ }^{4} \mathrm{U}$ tom je kontekstu zanimljivo i to što se pojmovi "dosada” i “interesantno" u rječnicima pojavljuju u istom periodu (vidi Bezinović 2007: 15)

5 Tako će Kuvačić (1965), u tekstu “O rutinizaciji života”, napisati kako sveprožimajuća birokratizacija proizvodi rutinizaciju koja zahvaća sve segmente društva i čovjekova života. Kombinacija birokratizacije i rutinizacije nastoji održati društveni i ekonomski sistem, transformirajući kreativno djelovanje u egzaktno i mehaničko obavljanje preciznih zadataka s ciljem brzih i efikasnih operacija. Na taj način, razvija se specifičan tip racionalnosti koji čovjek internalizira, poprimajući pritom osobine samoga sistema: "rad se šablonizira", piše Kuvačić, a "gigantski kalkulator povija život u pravcu bezdušne koordinacije koja guši kreativnu djelatnost".
} 
alate jedne određene discipline ili teorijsko-metodološkog pravca. Naime, ukoliko bi se dosadu, imajući na umu spomenuti status pojma u društveno-humanističkoj sferi, pokušalo uokviriti isključivo u određeni registar, zanemarujući pritom neke druge perspektive i pristupe, analiza bi bila lišena produktivnijih momenata koji mogu proizaći iz kombinacije više registara. Kao što je širi historijski zahvat, u kojem su svoje mjesto našli pristupi koji naginju prema filozofiji, sociologiji ili antropologiji, bio nužan kako bi se što jasnije i preciznije skicirao povijesni kontekst u kojem dosada postaje društveno relevantan fenomen, sličnu je stvar potrebno napraviti i prilikom postavljanja konceptualnih okvira koji mogu pružiti širi pogled na dosadu. Imajući na umu tekstualni prostor na raspolaganju, teško je očekivati da će ovaj članak uspjeti ponuditi podrobniji pregled svih, ili čak i većine, mogućih pozicija s kojih se dosada može konceptualizirati i analizirati. U ovom se poglavlju, kao i u ostala dva potpoglavlja, analiza ograničava na nekoliko pristupa, između kojih se u prvi plan postavljaju onaj filozofski i onaj sociološki. Time se nastoji što više "pokriti" teren, počevši od filozofsko-ontološke dimenzije dosade, pa do socioloških tumačenja dosade koja se baziraju na konkretnim empirijskim istraživanjima.

Po pitanju filozofskog razmatranja dosade, najbolje bi bilo osvrnuti se na Svendsena. Svendsen (2005: 45) piše kako je dosadu nemoguće definirati zbog nedostatka pozitivnih značenja i afirmativnih stajališta. Dosada je, prema njemu, odsutnost koja se veže uz neprisutnost osobnoga smisla. Kod Svendsena je dosada izjednačena s nepostojanjem, nemanjem i odsustvom "nečega". Prateći to stajalište, moglo bi se reći kako se dosada shvaća isključivo u relaciji s drugim konceptima i stanjima. $U$ tom slučaju, koncepti i stanja koji se nalaze na suprotnoj strani su, na neki način, u nadređenom položaju, jer jedino u slučaju njihove odsutnosti, dolazi do manifestacije dosade. No, čak i u slučaju manifestacije dosade, potrebno je uočiti i odgovoriti na pitanje - čega, u partikularnom stanju dosade, nema? Što je odsutno? Dakle, kako bi se shvatilo specifično stanje dosade, pogled se ne usmjerava na samu dosadu, već na stanja i iskustva koja nedostaju. Tako se dosada shvaća u "klasičnom" sustavu binarnih opozicija te u okvirima onoga što se naziva metafizikom prisutnoga. Kao što se, unutar tih okvira, noć može shvatiti kao odsutnost dana, kojemu se pridaje afirmativna definicija, tako se i dosada kod Svendsena shvaća kao odsutnost smisla. Jedan je pojam nadređen drugome; drugi se definira samo kroz odnos s prvim; drugi reflektira odsustvo prvoga. Za Svendsena dosada tako postaje gubitak pravca i veze sa svijetom, nedostatak volje i snage da se učini ono što se želi učiniti, pa čak i "ne-život" (isto: 41).

Conrad dijeli djelomice slična stajališta koja je izgradio na temelju empirijskog istraživanja o kojem će biti riječ nešto kasnije u tekstu. No, u svom radu pokušava postaviti širu konceptualizaciju dosade. Elaborirajući teze i definicije nekolicine autora, Conrad označava dosadu u najširem smislu kao neugodno afektivno stanje, kao alijenaciju od trenutka. Dosada je, za Conrada (1997: 468), društveni konstrukt - dosada je kategorija korištena u svakodnevici kako bi se izrazilo i opisalo stanje nezainteresiranosti, lijenosti ili situacije, objekta i iskustva koji prouzrokuju osobno nezadovoljstvo i neispunjenost. Prema tome, Conrad definira dosadu kao odnos, jer se ona manifestira samo u relaciji između subjekta 
i iskustva, situacije ili nekog objekta. Dosada je, prema tim postavkama, shvaćena kao afektivno stanje koje proizlazi iz subjektivne interpretacije pojedine situacije, iskustva ili objekta koji se potom označava dosadnim. Conrad naglasak stavlja na subjekt, negirajući pritom mogućnost da dosada bude shvaćena kao intrinzično svojstvo nekog iskustva, situacije ili objekta. Za Conrada (isto) ne postoji ništa što je dosadno per se, jer ono što je dosadno za nekoga, nije nužno dosadno za druge.

I Barbalet (1999: 636), poput Conrada, ističe važnost interpretacije prilikom doživljavanja, ali i prilikom analiziranja i teoretiziranja dosade, odnosno prilikom definiranja i sistematiziranja dosade kao koncepta. Za razliku od Svendsena, koji se u analizi dosade zadržava na metafizičkoj razini, i Conrada, koji dosadu prvenstveno sagledava u kontekstu (među) odnosa, Barbalet - iako baziran na sociološkom pristupu - pokušava razložiti dosadu u kognitivnom i psihološkom registru, čime dodatno širi mogućnosti razumijevanja fenomena. Naime, Barbalet tvrdi da dosada nije nagon, već emocija. Emocije, prema njemu, zahtijevaju određene interpretativne okvire (simboličke i društvene) koji omogućavaju njihovu aktivaciju, dok kod nagona nije tako. Subjekt interpretira pojedino emotivno stanje, dok nagoni izmiču refleksiji; osoba, putem procesa interpretacije određene situacije, okruženja ili objekta, doživljava dosadu kao emociju. Dosada se, prema Barbaletu, aktivira samo onda kada manjak interesa stvara u subjektu osjećaj nemira, nelagode i nezadovoljstva. Dakle, čovjek doživljava dosadu onda kada je u refleksivnom odnosu s danim kontekstom ili objektom koji u njemu izazivaju osjećaj nelagode i nemira; uzrok nelagode i nemira pronalazi u manjku interesa, na temelju kojega svoju poziciju i kontekst u kojemu se nalazi izjednačuje s besmislom iz razloga što ne vidi svrhu, smisao i značenje određene situacije, akcije ili objekta. Sumirajući, Barbalet (isto: 637 ) dosadu shvaća kao "emotivno poimanje besmisla": ukoliko osoba u specifičnim situacijama, aktivnostima ili objektima ne uočava ili ne uspijeva konstruirati smisao i značenje, ona upada u stanje dosade.

Toohey (2011), s druge strane, nudi nešto "jednostavniji” prikaz dosade; za njega je dosada povezana s monotonijom, repetitivnošću i ograničenošću. "Istost" nekog objekta, osobe ili situacije proizvodi u subjektu stanje dosade. Pod istošću, Toohey podrazumijeva nepromjenjivost i predvidivost: dosada se manifestira u onim slučajevima u kojima čovjek doživljava ili konzumira ono što mu je već poznato, ono što mu ne nudi nikakvu promjenu ili novost. Izloženost čovjeka repetitivnim i monotonim iskustvima proizvodi osjećaj zasićenosti, koji za Tooheyja predstavlja jedan od tipova dosade. lako se nalazi na rubu psihološke domene, Tooheyjeva je interpretacija slična onoj Conradovoj: dosada se manifestira u odnosu prema osobama, situacijama, objektima itd.

Višeslojnost koncepta dosade je, na neki način, uokvirena i sumirana kod Elpidoroua (2015), koji problematici pristupa kombinirajući filozofsko-egzistencijalistički i psihološki rakurs. Naime, prema shvaćanju Elpidoroua, dosada je relacijska, situacijska i višeznačna: relacijska, jer se stvara u odnosu; situacijska, jer se manifestira u pojedinim situacijama i društvenim okruženjima; njeno značenje je mnogostruko, jer ovisi o subjektu i subjektivnim željama, interesima, očekivanjima i - interpretaciji. 


\section{TIPOLOGIJA DOSADE}

Nakon pregleda nekoliko različitih pokušaja konceptualizacije dosade, u kojima je vidljivo kako se dosada većinom definira u negativnim terminima, otvara se pitanje - s obzirom na raznovrsnost pristupa i konceptualizacija koje iz njih proizlaze, je li moguće sustavno postaviti određenu tipologiju dosade? Takvi pokušaji u dostupnoj literaturi već postoje. Primjerice, Martin Doehlemann (prema Svendsen 2005: 41-42) dijeli dosadu na četiri tipa: situacijsku dosadu, dosadu zasićenosti, egzistencijalnu dosadu i kreativnu dosadu. Dalje, Toohey (2011) dijeli dosadu na "običnu" i "egzistencijalnu”, dok se Svendsen zadržava na podjeli između situacijske i egzistencijalne dosade. Kod Conrada se npr. u prvom planu ističe situacijska dosada. Iščitavajući radove navedenih autora, može se uočiti kontinuirano naglašavanje situacijske dosade i one egzistencijalne. Na temelju toga, ovdje se članak ograničava samo na dva potonja tipa dosade, ne ulazeći u elaboraciju ostalih mogućih tipova. Time se ne nastoji umanjiti analitičku vrijednost, primjerice, Doehlemannove dosade zasićenosti i dosade kreativnosti. Zapravo, i dosadu zasićenosti i dosadu kreativnosti moguće je, na temelju primjera, uklopiti u okvire situacijske dosade, za čiji je prikaz adekvatnije prijeći u sociološki registar, dok je onu egzistencijalnu adekvatnije pokušati skicirati u filozofskom i, djelomice, psihološkom okviru.

\section{SITUACIJSKA DOSADA}

Prihvati li se Conradova teza o nepostojanju intrinzičnog svojstva dosade pojedinih iskustava ili objekata, moglo bi se reći kako je u središtu situacijske dosade subjektivni doživljaj i osobna interpretacija situacije u kojoj se subjekt nalazi. Situacijska se dosada, dakle, manifestira u određenim društvenim okruženjima, odnosima ili radnjama. Taj se tip dosade, za Svendsena (2005: 42), može izraziti i artikulirati putem jezika, gestikulacija ili "govorom tijela". Primjerice, zijevanje, duboki izdisaji ili izležavanje na nekom predavanju mogu asocirati na manifestaciju situacijske dosade. U psihološkom smislu, osjećaji koji se mogu pojaviti prilikom doživljavanja situacijske dosade su osjećaji nelagode, gubljenja vremena ili beskorisnosti određene situacije. Kako bi empirijski istražio dosadu, Conrad (1997) je proveo istraživanje na uzorku od trideset pet studenata. Studentima je bilo dano da zapišu vlastiti doživljaj nekog nedavnog iskustva koje smatraju dosadnim, što se odnosilo na njihova osobna iskustva te iskustva na fakultetskim predavanjima. Conradov zaključak iznosi dvije karakteristike dosade u određenim situacijskim okvirima: prva uključuje manjak stimulacije, druga se odnosi na osjećaj isključenosti iz dane situacije.

U razmatranju potonje karakteristike situacijske dosade, osjećaja isključenosti, Conrad je analizom izjava studenata zaključio da je posrijedi nemogućnost uspostavljanja odnosa s određenim iskustvom ili situacijom. U navedenom je slučaju Conrad fokusirao istraživanje na studentske doživljaje fakultetskih predavanja. Studenti su upadali u stanje dosade zbog niza faktora. Prvi je neznanje ili nepoznavanje teme o kojoj se na predavanju govorilo, što je 
sprječavalo studente da se s tematikom povežu; drugi je dobro i široko poznavanje teme, što je u studentima proizvodilo osjećaje zasićenosti a što ukazuje na manifestaciju Doehlemannove dosade zasićenosti u ovom partikularnom slučaju; treći je faktor repeticija već poznatog, a četvrti se faktor odnosi na kompleksno, nerazumljivo gradivo i profesorsko izlaganje. Conrad zaključuje da imanje ili nemanje predispozicija i predznanja za određenu aktivnost ili danu situaciju može prouzročiti stanje (situacijske) dosade.

Manjak stimulacije podrazumijeva manjak poticaja iz okruženja u kojem se pojedini studenti nalaze. Dakle, studentima je bilo problematično to što nisu dobivali, ili nisu mogli pronaći, nešto što bi ih moglo potaknuti na djelovanje, motivirati i zainteresirati. Studenti “nisu imali što raditi" (Conrad 1997: 470), što se odnosi na nemogućnost pronalaženja nekog objekta ili moguće radnje putem kojih bi mogli izaći iz stanja dosade. U njihovim se bilješkama istaknula problematika neiskorištenog vremena i njegova spora prolaznost, kao i nedostatak socijalne interakcije. Studenti su u odnosu s okruženjem doživljavali dosadu jer u neposrednom okruženju nisu mogli pronaći ništa zanimljivo. Tu se manifestira i Doehlemannova dosada kreativnosti: zbog stanja dosade, studenti su tražili neke nove stimulacije i radnje, ali nisu mogli pronaći kreativan "izlaz" iz dosade. Svendsen ističe da je promjena situacije moguće rješenje za taj tip dosade. U tom smislu, situacijsku bi se dosadu moglo okarakterizirati kao privremenu i blažu formu dosade koja se može manifestirati kako u situacijama koje podrazumijevaju kolektivne aktivnosti tako i u situacijama u kojima se subjekt nalazi u odnosu s objektima ili radnjama - npr. gledajući televiziju, vozeći se autobusom, sjedeći duže vrijeme u čekaonici itd.

\section{EGZISTENCIJALNA DOSADA}

Dok se u vezi situacijske dosade mogu pronaći "instant" rješenja (promjena situacije) i određeni elementi (bihevioralni, psihološki ili društveni) koji izražavaju i ukazuju na postojanje dosade, egzistencijalna dosada produbljuje ovu problematiku. Moglo bi se reći da je ona dugotrajnija, da prožima mnogo više iskustava od one situacijske te da je na neki način uključuje i nadilazi. Svendsen (2005: 42) piše da je egzistencijalna dosada "dublja" od one situacijske - za razliku od nje, egzistencijalna je dosada lišena izražavanja. Stanje egzistencijalne dosade okarakterizirano je nemogućnošću pronalaženja objekta koji bi utažio želju čovjeka za bilo kojim tipom angažmana koji bi proizveo osjećaj ispunjenosti, svrhovitosti i smislenosti. Svendsen ide korak dalje i piše kako u egzistencijalnoj dosadi čovjek ni ne zna što zapravo želi. Na taj način, egzistencijalna dosada postaje sveprožimajuća, jer ispunjava odnos nekog subjekta s gotovo svim objektima, situacijama i aktivnostima s kojima se susreće (Elpidorou 2015). Prateći Barbaletove postavke, moglo bi se reći da subjekt u tom stanju ne može pronaći smisao ni značenje gotovo nigdje. U momentu refleksije i autorefleksije, subjekt ne pronalazi moguće rješenje, ali ni bilo kakav način da reagira na stanje dosade u kojemu se nalazi. Egzistencijalnu dosadu Toohey (2011: 27) povezuje s prazninom nastalom zbog osjećaja izolacije: čovjek vidi sebe kao izoliranu jedinku koja u 
fragmentiranom (modernom) društvu ne može pronaći uporište smisla i značenja. Tako se dosada približava stanjima ravnodušnosti, otuđenja i neproduktivnosti. Preciznije, egzistencijalna dosada kao da "koketira" s raznim psihološkim i emocionalnim poremećajima. Upravo je zbog toga poprilično teško ocrtati jasne granice distinkcije između tih dviju razina. Zbog toga Toohey (2005: 25) sasvim ispravno kritizira konceptualizaciju egzistencijalne dosade, smatrajući je intelektualnom, a ne iskustvenom i emotivnom problematikom: više se ljudi bavilo analizom i intelektualnim raščlanjivanjem egzistencijalne dosade nego što ju je iskusilo i doživjelo. Egzistencijalni tip dosade je, prema njegovom mišljenju, oblik depresivnog stanja koji je zbog silnog interesa istraživača postao "intelektualiziran" i samim time "nadišao" klinički problem depresije te postao "filozofska bolest". Zbog mnogih nejasnoća u definiranju egzistencijalne dosade, za daljnju raspravu ne bi bilo produktivno širiti problematiku. Međutim, s obzirom na problematične aspekte koje egzistencijalna dosada poprima u psihološkim okvirima gdje gubi svoje konceptualne granice i "stapa" se s drugim psihološkim stanjima, trebalo bi je pokušati sagledati u nekom drugom registru koji bi bar djelomice mogao razjasniti njeno značenje. Primjerice, u historijskom okviru dobiva se malo drukčija slika: zanimljivo je to što upravo Toohey piše da je, za razliku od situacijske dosade ${ }^{6}$ koja se manifestirala u društvenim formacijama prije 18. stoljeća, egzistencijalna dosada onaj tip dosade koji se nametnuo i proširio u europskoj moderni. Kao potencijalne uzroke, Toohey spominje raspad tradicionalnih odnosa, rast alijenacije i izolacije te - ono što je važno za nastavak članka - komercijalizirane dokolice.

\section{RIJEŠITI SE DOSADE - ZABAVA I TRŽIŠTE}

Odnos dosade i dokolice, koji je uveden referiranjem na Tooheyja, ne podrazumijeva to da su dokolica i dosada u neraskidivoj vezi, ili da jedna podrazumijeva drugu. Kao što je prethodno navedeno, dosada se može manifestirati i na fakultetskim predavanjima, prilikom odrađivanja nekog posla itd. Drugim riječima, dosadu se može iskusiti bilo kada i bilo gdje - bilo to u kontekstu monotonih i repetitivnih radova, ili pak u slučaju pomanjkanja stimulacija u slobodnom vremenu. S obzirom na to da bi se odnos dosade i dokolice u širem smislu mogao proširiti na zasebno poglavlje, za ovu je raspravu produktivnije fokusirati se na odnos dosade i raznih komercijalnih sadržaja i aktivnosti koje se nude kao rješenja protiv dosade upravo u (komercijaliziranoj) dokolici.

Već u periodu romantizma dolazi do distinkcije između onoga što nudi napredak i razvitak, i onoga što čovjeka može unazaditi ili zaustaviti u razvoju - razlikuje se ono što je zanimljivo i novo, te ono što je dosadno; prvo treba tražiti i konzumirati, drugo izbjegavati. Ono zanimljivo i novo kao da samo po sebi obećava napredak, intelektualni i duhovni razvitak, individualni rast i razvoj. Stoga, "gubljenje vremena" u takvom kontekstu zvuči

${ }^{6}$ Toohey koristi pojam "obične" dosade, ali su značajke u principu istovjetne onima situacijske dosade. Zbog koherentnosti teksta, ostajem pri situacijskoj varijanti. 
poprilično negativno, pa čak i pogubno. Biti čovjek (post?)moderne znači biti čovjek u pokretu, konzumirati nove proizvode, nadograđivati vlastiti identitet. Pod svaku cijenu treba izbjeći stanje dosade ili, možda još gore za vlastitu društvenu poziciju, biti dosadan u očima drugih. No, kako u birokratiziranom i rutiniziranom okruženju pronaći adekvatno "instant" rješenje, pronaći svojevrstan lijek protiv dosade?

Na pamet padaju mnoga komercijalna rješenja ili, drugim riječima, kombinacija kulturne industrije i konzumerizma. Horkheimer i Adorno (2002: 113) u poglavlju o kulturnoj industriji pišu kako ona obećava bijeg iz svakodnevnog svijeta. Dakle, moglo bi se reći da kulturna industrija potrošačima nudi, ili nastoji ponuditi, konstantno nove i zanimljive sadržaje čijom će konzumacijom oni izaći iz onog običnog, banalnog, monotonog i - dosadnog. Dovoljno je prisjetiti se slogana televizijskoga programa RTL2 - Samo zabava, koji kao da nastoji interpelirati gledatelje sugerirajući da na suprotnoj strani, odnosno na drugim televizijskim programima ili u "praznini” njihova doma, negdje u pozadini prijeti sjena dosade. Slogan Samo zabava kao da garantira cjelodnevnu, kontinuiranu izloženost različitim medijskim sadržajima koji ne mogu dosaditi, te koji bi stoga trebali biti privlačni, stimulativni i zaokupljujući. Pitanje je, međutim, koliko je takva vrsta eskapizma efektivna, i koliko je potrebno da se u vremenu sve intenzivnije produkcije i reprodukcije kulturno-medijskih proizvoda slogan Samo zabava u očima gledateljstva pretvori u vlastitu antitezu, u slogan Samo dosada.

Christopher Lasch, s druge strane, piše da reklama "stvara vlastiti proizvod: vječno nezadovoljnog, nespokojnog, tjeskobnog i dosadom mučenog potrošača” (1986: 82, istaknuo autor), promovirajući tako potrošnju kao stil života, stvarajući žudnju za novim iskustvima i novim proizvodima, ujedno obećavajući ispunjenje praznine i rješavanje svih nezadovoljstava. Ukoliko je, prema Svendsenu, dosada privilegija modernoga čovjeka, a, prema Conradu, neugodno afektivno stanje, moglo bi se reći da reklama, prateći Laschove teze, obećava riješiti i problem dosade. Kako bi konzumerističke prakse mogle "riješiti" problem?

Hajrudin Hromadžić (2008: 46) piše kako je shopping mall "ultimativni potrošački teritorij". Trgovački centri, naime, osim što nude mnoštvo različitih proizvoda, nude posjetiteljima razne sadržaje, poput restorana, kina, igraonica itd. Prostor trgovačkog centra nudi potrošačima mogućnost doživljavanja različitih iskustava, što vidno utječe i na redefiniranje potrošačkih praksi: "Kupovanje postaje zabava, zabava je kupovanje" (isto: 49). Moglo bi se, dakle, reći da trgovački centri stvaraju određene situacije, potiču određena iskustva, nude nove, moderne i različite proizvode, ujedno i zabavljaju te nude, kolokvijalno rečeno, "za svakoga ponešto". Na taj način, kao da nastoje obuhvatiti prethodno izložene elemente dosade: situacijsku, iskustvenu, predmetnu i višeznačnu razinu. Obuhvaćajući ih, trgovački centri kao da nude adekvatan, iako vremenski ograničen, "lijek” protiv dosade. Samim time, "napadaju" i relacijsku razinu dosade, tako što posjetitelj, kada je jednom uronjen u trgovački centar, stupa u raznovrsne i mnogostruke odnose kako u smislu socijalnih interakcija tako i u odnosima s različitim predmetima, znakovima i simbolima. Korak dalje u 
konzumerističkim praksama čini koncept protrošača, koji podrazumijeva svojevrstan spoj proizvođača i potrošača, "s ciljem označavanja kako kreativnog sudjelovanja u proizvodnji, tako i činjenice da činom kupovine proizvodimo određenu vrijednost, da smo zapravo kroz aktivnosti kupnje produktivni" (isto: 79). Ukoliko je kreativno djelovanje, kao što je naznačeno u bilješci pod brojem 5 referiranjem na Kuvačića, "ugušeno" rutinizacijom i birokratizacijom svakodnevice, izgleda kao da dolazi do svojevrsne kompenzacije manjka takvog djelovanja upravo u sferi tržišta, u ulozi protrošača. Na taj način, subjekt stvara i konzumira, upisuje i iščitava značenja koja želi. Moglo bi se reći da subjekt i osmišljava samu praksu, a u njoj, kao i u konačnom proizvodu modeliranom prema vlastitim željama i interesima, može pronaći određenu dozu stimulansa, ispunjenja i smisla. Takva vrsta personalizirane potrošnje i konzumacije proizvoda otvara prostor za kreativnost i produktivnost potrošača, te mogućnost ne samo definiranja i redefiniranja proizvoda već i interpretacije i reinterpretacije potrošačkih praksi, a u skladu s time i samih proizvoda. Time se zadaje "udarac" i elementu subjektivne interpretacije kao sastavnom elementu dosade. Naime, ukoliko jedan proizvod i određeni model potrošačke prakse dosadi, subjekt se može upustiti u redefiniranje i reinterpretiranje prakse i proizvoda kroz perspektivu protrošača. U tom pogledu, tržište kao da nudi beskrajan niz mogućnosti za takvo što.

Dakle, moglo bi se reći da se konzumerizam, kao poluga kapitalizma, predstavlja kao "lijek" protiv dosade, kao adekvatno i pristupačno rješenje, pa čak i kao antipod dosade. Tako i sama dosada postaje plodno tlo za stjecanje profita. Preciznije, izbjegavanje dosade kao da postaje imperativ, a naglašavanje zabave i novih iskustava neizbježan segment većine reklamnih kampanja. Ako "svakodnevica nadomješta kolonije", kako to tvrdi Lefebvre (1988: 516), ako je svakodnevica eksploatirana i, stoga, uklopljena u kapitalistički sustav prema čijim se obrascima modelira oko njegovih temeljnih principa, onda je legitimno zaključiti da je i dosada, kao element svakodnevice, jedan od faktora koji pokreću potrošačku, konzumerističku mašineriju. Pitanje je, ponovno, koliko je takav “lijek” protiv dosade učinkovit. Što ako, zapravo, takav sustav ne odstranjuje dosadu, nego je perpetuira? Što ako i sve te prakse dosade?

\section{UMJESTO ZAKLJUČKA - DOSADA KAO DRUŠTVENA KRITIKA?}

“Dosada se mora prihvatiti kao nezaobilazna činjenica”, piše Svendsen (2005: 154). Međutim, dosada ne mora nužno predstavljati samo i isključivo neugodno afektivno stanje, kao što to sugerira Conrad (1997) i kao što je vidljivo kod mnogih koji pokušavaju definirati dosadu. Barbalet, na primjer, tvrdi da je dosada aktivan nemir: dosada, za Barbaleta (1999: 41), može potaknuti istraživanje, radoznalost, kreativnost i invenciju, što za sobom povlači i mogućnost konstruiranja smisla i značenja. Elpidorou (2015) ide i korak dalje, tvrdeći da dosada predstavlja motivirajući potencijal promjene. Za Elpidoroua, dosada može potaknuti čovjeka na djelovanje, ona sadrži želju za promjenom, te otvara prostor za refleksiju i autorefleksiju. Ona je reakcija na problem (isto: 274-275). Uz to, dosada je za čovjeka 
i informativna: iščitavanjem tog stanja, on može analizirati situaciju u kojoj se nalazi, te steći uvid u vlastite interese i ciljeve (isto: 278). Stoga, za Elpidoroua, dosada nije problem, nego dio rješenja. Dosada je svojevrstan orijentir: naglašava trenutnu situaciju, čime subjekt spoznaje njenu beznačajnost i ispraznost, shvaćajući pritom da postoji i mogućnost alternative, potencijal promjene. Uz navedene mogućnosti, izgleda kako dosada otvara još jednu mogućnost.

Prema sugestiji Highmorea (2002: 11), dosada može biti iskorištena za dijagnozu stanja društva, dosada može biti i obilježje društvene kritike.? Na tom tragu, gledano iz subjektivne perspektive pojedinca u suvremenom društvenom kontekstu, pruža li dosada jednu od rijetkih mogućnosti distanciranja od konzumerističkih i kulturno-industrijskih upliva u život i strukturu svakodnevice? Odnosno, može li se dosadu shvatiti s jedne strane kao moment "izlaska" iz svakodnevice prožete tržišno-potrošačkom logikom, a s druge kao alat "kritike" bogatog i šarenog repertoara izloženih roba i komodificiranih iskustava u, kako bi ga Gilles Lipovetsky (2008) nazvao, hiperpotrošačkom društvu?

Izgleda kako se u stanju dosade može zauzeti pozicija koja nudi zanimljiv potencijal otpora i mogućnost demistifikacije dotad zdravorazumski percipirane svakodnevice. Dosada se, tako, može shvatiti i kao svojevrsna praksa: praksa odbijanja gotovo pa i nametnutog dominantnog modela konstantnog (su)djelovanja i bivanja kreativnim i inovativnim u svim aspektima svakodnevice, što podrazumijeva imperativ rada na sebi koji je nerijetko modeliran prema principima i zahtjevima dinamike tržišta, te sveprisutne (inter)aktivnosti koja je nerijetko samoj sebi svrha. Sagledana u tom ključu, dosada se može shvatiti kao praksa odbijanja dominantnih ideoloških obrazaca koji "slave" stopostotnu predanost radu na sebi s ciljem bivanja u ritmu s tržišnim mijenama, sveopću kreativnost industrijaliziranog polja kulture i umjetnosti, te maksimalizaciju produktivno iskorištenog vremena čija "suhoparna" prolaznost stvara osjećaj krivnje zbog neiskorištenih mogućnosti, pa bi je stoga valjalo bilo kakvim sredstvima izbjeći. Uz to, dosada može poprimiti oblik prakse odbijanja (su) djelovanja u potrošačkim aktivnostima koje spomenuti ideološki obrasci predstavljaju kao modele samorealizacije pojedinca, kao aktivnosti putem kojih pojedinac može (re)kreirati sebe. S druge strane, sagledano iz perspektive dominantnog modela i obrazaca, dosada predstavlja suštu suprotnost poželjnim karakteristikama suvremenog kreativnog, dinamičnog i produktivnog subjekta ili, preciznije rečeno, naturaliziranom poimanju svakodnevice kao poligona tržišne i potrošačke eksploatacije. Možda bi upravo u tom pogledu dosada mogla biti "privlačna" u vidu teorijske artikulacije onih aspekata svakodnevice koji mogu poprimiti oblik pauze, refleksije i odmaka od "kapitalističke igre", onih aspekata svakod-

\footnotetext{
${ }^{7} \mathrm{Na}$ tom tragu, grupa autora (Jervis i dr. 2003) analizira dosadu u kontekstu svakodnevnog života u jednom sjevernoameričkom rezervatu, ističući da artikulacija dosade od strane ispitanika predstavlja i glas protesta protiv uvjeta života u rezervatima, dok druga grupa autora (Moynihan i dr. 2015) analizira odnos dosade i prehrane: pretjerana konzumacija "nezdrave" hrane shvaćena je kao svojevrstan bijeg od dosade. Dakle, dosada kao koncept može poslužiti u kritičkoj analizi društvenih fenomena i problema - od rasnih, rodnih i klasnih, do političko-ekonomskih, kulturoloških, obrazovnih itd. Bilo bi, stoga, zanimljivo proširiti istraživanja dosade i analizirati je, primjerice, u okvirima klasnih struktura i odnosa, ili getoizacije određenih skupina, ili pak u okvirima birokratiziranog bolonjskog procesa, konzumacije medijskih sadržaja, potrošnje itd.
} 
nevnog života koji, makar i kratkotrajno, čovjeku omogućuju određeni stupanj autonomije, izolacije, pa čak i slobode misli, (ne)djelovanja, refleksije. Možda bi, na tom tragu, dosada mogla biti i poželjno, pa čak i nužno stanje. ${ }^{8}$

Dakako, kritički i refleksivni "potencijal" dosade zahtjeva podrobnije istraživanje i propitivanje, pa i dodatnu terensku provjeru. Zahtjeva analizu u konkretnijim situacijama. Isto tako, valjalo bi oprezno pristupati konceptu i fenomenu dosade, s obzirom na sveobuhvatnost komodifikacijskih procesa i izglednih mogućnosti preobražaja dosade u specifičan lifestyle, procesa koji bi od kritičkog i refleksivnog potencijala dosade učinili još jedan identitetski dekor. Imajući to na umu, o dosadi kao obliku društvene kritike treba razmišljati kako bi se proširilo shvaćanje tog fenomena, izbjegavajući pritom označavanje dosade kao isključivo negativnog stanja, što već u samom polazištu sužava prostor analize. U dosadi se može detektirati odraz društva i njegovih problematičnih elemenata, dok se u samome društvu, koristeći dosadu kao analitički koncept, mogu vočiti faktori koji utječu na njenu manifestaciju, a paralelno i na svakodnevni život. Stoga, iako sama dosada kao specifično stanje nije dovoljna za širu i snažniju kritiku suvremenog socioekonomskog konteksta, ne bi je se trebalo unaprijed odbacivati kao negativnu ili trivijalnu pojavu, već bi bilo korisno uzeti je u obzir prilikom pokušaja artikulacije analize i kritike svakodnevnog života, shvati li se potonji kao "baza" materijalnih uvjeta života pojedinaca te, u skladu s time, kao polazišna točka čvrsto argumentirane, emancipacijski nastrojene i, zašto ne, utopijski oblikovane kritike aktualnog društvenog stanja.

\section{NAVEDENA LITERATURA I IZVORI}

Barbalet, Jack. 1999. "Boredom and Social Meaning". The British Journal of Sociology 50: 631-646. [https://doi.org/10.1080/000713199358572]

Bezinović, Igor. 2007. Socijalna konstrukcija dosade. Diplomski rad. Filozofski fakultet u Zagrebu: Odsjek za sociologiju.

Conrad, Peter. 1997. "It's Boring. Notes on the Meanings of Boredom in Everyday Life". Qualitative Sociology 20/4: 465-475. [https://doi.org/10.1023/A:1024747820595]

Dalle Pezze, Barbara i Carlo Salzani, ur. 2009. Essays on Boredom and Modernity. Amsterdam: Rodopi. Elpidorou, Andreas. 2015. "The Significance of Boredom. A Sartrean Reading”. U Philosophy of Mind and Phenomenology. Conceptual and Empirical Approaches. Daniel O. Dahlstorm, Andreas Elpidorou i Walter Hopp, ur. London, New York: Routledge, 268-283.

Highmore, Ben. 2002. Everyday Life and Cultural Theory. London, New York: Routledge.

Horkheimer, Max i Theodor W. Adorno. 2002. Dialectic of Enligthenment. Philosophical Fragments. Stanford: Stanford University Press.

Hromadžić, Hajrudin. 2008. Konzumerizam. Potreba, životni stil, ideologija. Zagreb: Naklada Jesenski i Turk.

${ }^{8}$ Pritom valja naglasiti kako se ovdje ne misli na permanentno stanje dosade. 
Jervis, Lori L., Paul Spicer, Spero M. Manson i The AI-SUPERPFP Team. 2003. "Boredom, "Trouble" and the Realities of Postcolonial Reservation Life". Ethos 31/1: 38-58. [https://doi.org/10.1525/ eth.2003.31.1.38]

Kuvačić, Ivan. 1965. “O rutinizaciji života”. Praxis 2/4-5: 668-675.

Lasch, Christopher. 1986. Narcistička kultura. Američki život u doba smanjenih očekivanja. Zagreb: Naprijed.

Lefebvre, Henri. 1988. Kritika svakidašnjeg života. Zagreb: Naprijed.

Lipovetsky, Gilles. 2008. Paradoksalna sreća. Ogled o hiperpotrošačkom društvu. Zagreb: Biblioteka Antibarbarus.

Moynihan, Andrew B., Wijnand A. P. van Tilburg, Eric R. Igou, Arnaud Wisman, Allan E. Donnelly i Jessie B. Mulcaire. 2015. "Eeaten Up by Boredom. Consuming Food to Escape Awareness of the Bored Self". Dostupno na: https://www.frontiersin.org/articles/10.3389/fpsyg.2015.00369/full (pristup: 10. 6. 2017.).

Musharbash, Yasmine. 2007. "Boredom, Time and Modernity. An Example from Aboriginal Australia". American Anthropologists 109/2: 307-317. [https://doi.org/10.1525/aa.2007.109.2.307]

Svendsen, Lars. 2005. A Philosophy of Boredom. London: Reaktion Books.

Toohey, Peter. 2001. Boredom. A Lively History. New Haven, London: Yale University Press.

\section{ON BOREDOM: A DRAFT FOR A POSSIBLE CRITIQUE}

The paper is divided into two parts. The first part focuses on contextual, conceptual, psychological and experiential characteristics of boredom, while the second examines contemporary consumer practices which are viewed as practices that offer a possible "solution" for boredom. The first step sketches the socio-cultural context in order to locate the manifestation and development of boredom as a concept and a socially relevant phenomenon. The second step gives an overview of different approaches to boredom in order to draw a broader conceptual and theoretical framework. Two types of boredom are closely examined: situational and existential boredom. The third step raises the question - are there any practices that seek to offer a sort of a "cure" for boredom? Here, the focus is on consumerism, culture and the entertainment industry. Particular attention is given to the relation between everyday life, boredom and "anti-boredom" practices. The last part tackles the question - can boredom take the form of social critique?

Keywords: boredom; existential boredom; situational boredom; consumerism; everyday life 